\title{
Aktualisasi Pancasila sebagai Sumber Hukum dalam Pembentukan Undang-Undang
}

\author{
Arfa' $i^{\star}$, Bahder Johan Nasution ${ }^{\star \star}$, Febrian ${ }^{\star \star \star}$ \\ ^Program Doktor Ilmu Hukum Universitas Sriwijaya \\ arfaijambi@gmail.com \\ ${ }^{\star \star}$ Fakultas Hukum Universitas Jambi \\ ${ }^{\star \star \star}$ Fakultas Hukum Universitas Sriwijaya
}

\begin{abstract}
In the Indonesian legal system, Pancasila is the source of all sources of law, the basis of the national law, and functions as rechtsidee. With such a position, all positive laws should reflect and be in line with Pancasila values. This article aims at exploring how Pancasila values actualized in the legislation of law. This article demonstrates that despite the vital role of Pancasila as long the legislation of law is concerned, there are no clear indicators and variables indicating that a law has reflected and been in line with Pancasila values. It is also found that there is no model or mechanism for testing whether the law which under legislation has been appropriate and conformed with Pancasila. The current indicators and variables are the ones set by the Agency for National Law Development (BPHN) and the Agency for Pancasila Ideology Education (BPIP), and are used to evaluate a positive law. In fact, they are not the ones intended to to evaluate a law which is currently in the level of legislation. This article argues that in order to actualize Pancasila values in the established law, indicators and variables regarding Pancasila values need to be regulated in a law. Besides, it is encouraged that the evaluation and testing mechanisms be implemented during legislation process.
\end{abstract}

Keyword: Pancasila; the source of law; law; legislation. 


\begin{abstract}
Abstrak
Dalam sistem hukum Indonesia, Pancasila merupakan sumber dari segala sumber hukum, dasar hukum nasional, dan cita hukum. Dengan kedudukan yang demikian itu, maka sudah seharusnya semua hukum yang dibentuk mencerminkan atau selaras dengan nilai-nilai Pancasila. Artikel ini bermaksud menelusuri bagaimana nilai-nilai Pancasila diaktualisasi dalam pembentukan suatu undang-undang. Dalam artikel ini ditunjukkan, sekalipun Pancasila memiliki peran yang sangat penting bagi suatu undang-undang yang dibentuk, ternyata belum ada indikator dan variabel tentang undang-undang yang mencerminkan atau selaras dengan nilainilai Pancasila. Artikel ini juga menunjukkan, belum ada model atau mekanisme pengujian apakah undang-undang yang sedang dalam tahap pembentukannya telah sesuai dan selaras dengan Pancasila. Indikator dan variabel yang ada sejauh ini ialah yang ditetapkan oleh Badan Pembinaan Hukum Nasional dan Badan Pembinaan Ideologi Pancasila, dan digunakan untuk mengevaluasi suatu undang-undang yang telah berlaku, bukan yang sedang dalam tahap pembentukannya. Karena itu, agar nilai-nilai Pancasila semakin teraktualisasi dalam undang-undang yang dibentuk, maka indikator dan variabel tentang nilai-nilai Pancasila perlu diatur dalam undang-undang, dan mekanisme evaluasi dan pengujiannya perlu didorong agar dapat dilakukan pula pada saat undang-undang sedang dalam tahap pembentukannya.
\end{abstract}

Kata kunci: Pancasila; sumber hukum; undang-undang; pembentukan.

\title{
A. Pendahuluan
}

Artikel ini membahas aktualisasi Pancasila sebagai sumber hukum dalam tahapan pembentukan undang-undang. Aktualisasi Pancasila di sini dimaksudkan sebagai perihal mengaktualkan atau menjadikan nilai-nilai Pancasila betul-betul ada atau terkandung dalam undang-undang. ${ }^{1}$ Dalam artikel ini, pembahasan aktualisasi Pancasila difokuskan pada dua persoalan: pedoman aktualisasi nilainilai Pancasila yang diatur dalam undang-undang yang mengatur

1 Dalam Kamus Besar Bahasa Indonesia, aktualisasi diartikan "perihal mengaktualkan"; pengaktualan”. Sedangkan aktual sendiri diartikan antara lain sebagai "betul-betul ada". https://kbbi.web.id/aktualisasi, diakses $6 / 11 / 2020$. 
pembentukan undang-undang, serta mekanisme aktualisasi Pancasila sebagai sumber hukum dalam pembentukan undang-undang.

Pembahasan persoalan aktualisasi Pancasila dalam pembentukan undang-undang menjadi penting karena terkait kedudukan Pancasila itu sendiri. Bagi bangsa dan negara Indonesia, Pancasila merupakan ideologi ${ }^{2}$ dan dasar negara. Ideologi merupakan kerangka idealitas yang mengandung visi dan misi negara, yang memberi orientasi ke arah mana perjuangan dan pembangunan harus diarahkan, ${ }^{3}$ sedangkan dasar negara merupakan kerangka yuridis bagi terselenggaranya sistem ketatanegaraan untuk kelangsungan kehidupan bangsa dan negara. Karena itu, ibarat dua sisi mata uang, keduanya menempati kedudukan sendiri-sendiri namun dalam kesatuan fungsi praktik ketatanegaraan. ${ }^{4}$

Kerangka ideologi dan dasar negara dari Pancasila tersebut dalam sistem hukum nasional menempatkan Pancasila sebagai cita hukum. Cita hukum adalah gagasan, karsa, cipta, dan pikiran berkenaan dengan hukum atau persepsi tentang makna hukum. Cita hukum bukan hukum itu sendiri, melainkan "pra-pemahaman"

2 Pancasila sebagai ideologi merupakan kenyataan yang tidak bisa ditolak. Sebab, dalam setiap masyarakat selalu diharapkan tersedia keberadaan sebuah struktur bersama yang terbentuk dari ide-ide, dan karena itu salah satu fungsi penting lembaga sosial ialah mempertahankan dan menyebarkan ideologi bersama di antara mereka yang membentuk sebuah masyarakat. Agus Wahyudi, "Ideologi Pancasila: Doktrin yang Komprehensif atau Konsepsi Politis?”, Jurnal Filsafat, 39, 1 (2006), hlm. 105.

3 Yudi Latif, "Menjaga Negara-Bangsa, Menjaga Moral Republik: Menimbang Ulang Negara-Bangsa”, makalah dalam Orasi Widjojo Nitisastro Memorial Lecture, diselenggarakan Akademi Ilmu Pengetahuan Indonesia, https: / / www.aipi.or.id/assets/images/widjojo/file_1546620258.pdf, diakses $6 / 11 / 2020$.

4 Iriyanto Widisuseno, "Azas Filosofis Pancasila sebagai Ideologi dan Dasar Negara”, Humanika, 20, 2 (2014), hlm. 64.

5 B. Arief Sidharta, Ilmu Hukum Indonesia: Upaya Pengembangan Ilmu Hukum Sistematik yang Responsif terhadap Perubahan Masyarakat (Bandung: Unpar Press, cetakan kedua, 2017), hlm. 146; Maria Farida Indrati S., Ilmu Perundang-Undangan (Jenis, Fungsi dan Materi Muatan) Buku 1: Dikembangkan dari Perkuliahan Prof. Dr. A. Hamid S.Attamimi, S.H. (Yogyakarta: Kanasius, 2007), hlm. 60. 
tentang hukum, yang menjadi "bintang pemandu (leitstern)" hukum. ${ }^{6}$ Karena itulah tatanan hukum nasional harus bersumber utama pada Pancasila.' Kesesuaian tatanan hukum dengan cita hukum menunjukkan adanya aktualisasi objektif Pancasila, yaitu berupa realisasinya dalam berbagai tatanan hukum, ${ }^{8}$ termasuk undangundang 9 yang menjadi fokus artikel ini.

Namun demikian, di sisi lain, dalam perkembangan hukum nasional masih ditemui undang-undang yang tidak sesuai dengan nilai-nilai Pancasila. Hal ini terbaca, misalnya, dari evaluasi Badan Pembinaan Hukum Nasional (BPHN), yang pada 2019 menemukan empat dari sembilan undang-undang yang dievaluasi dinyatakan bermasalah. ${ }^{10}$ Hasil kajian Badan Pembinaan Ideologi Pancasila (BPIP) pada 2019 juga menyimpulkan, 63 dari 84 undang-undang perlu direvisi karena bertentangan dengan nilai-nilai Pancasila. ${ }^{11}$ Sementara

6 Hyronimus Rhiti, Cita Hukum dan Postmodern: Kajian Gagasan Ekologis Pancasila (Yogyakarta: Genta Publishing, 2020), hlm. 17.

7 Fais Yonas Bo'a, "Pancasila sebagai Sumber Hukum dalam Sistem Hukum Nasional”, Jurnal Konstitusi, 15, 1 (2018), hlm. 28.

8 Sutiyono, "Reaktualisasi Pancasila dalam Membentuk Good Citizenship di Era Global”, dalam Revitalisasi Ideologi Pancasila dalam Aras Global Perspektif Negara Hukum: Prosiding Seminar Nasional Dies Natalis Fakultas Hukum Unnes ke-9 Tahun 2016 (Semarang: Badan Penerbit Fakultas Hukum Universitas Negeri Semarang, 2017), hlm. 624.

9 Berdasarkan ketentuan Pasal 1 angka 3 Undang-Undang Nomor 12 Tahun 2011, undang-undang adalah peraturan perundang-undangan yang dibentuk oleh Dewan Perwakilan Rakyat dengan persetujuan bersama Presiden. Ia merupakan bentuk peraturan perundang-undangan yang sangat luas jangkauan materi muatannya. Dalam konsep asas legalitas bahkan dapat dikatakan, tidak ada lapangan kehidupan dan kegiatan kenegaraan, pemerintahan, masyarakat dan individu yang tidak dapat menjadi jangkauan untuk diatur oleh undang-undang. Abdul Latif, Hukum dan Peraturan Kebijaksanaan (Beleidsregel) pada Pemerintahan Daerah (Yogyakarta: UII Press, 2020), hlm. 123.

10 Badan Pembinaan Hukum Nasional Republik Indonesia, "Laporan Akhir Kelompok Kerja Analisis dan Evaluasi Hukum terkait Penguatan Ideologi Pancasila Tahun 2019”, https://www.bphn.go.id/data/documents/ laporan_akhir_pip.pdf, hlm. 167.

11 Ani Purwanti, "Advokasi dan Pengawasan Regulasi Badan Pembinaan Ideologi Pancasila, Rekomendasi Kebijakan dan Regulasi Berlandaskan Pancasila”, Paparan pada Seminar dan Presentasi Kajian, Analisis dan Rekomendasi Perundang-undangan Tahun 2020, diselenggarakan Badan 
itu, pengujian undang-undang di Mahkamah Konstitusi sejak 2003 sampai Januari 2020 menunjukkan terdapat 264 permohonan pengujian yang dikabulkan Mahkamah, ${ }^{12}$ yang berarti mengandung materi muatan yang bertentangan dengan ketentuan Konstitusi dan, lebih jauh dapat pula dikatakan, nilai-nilai Pancasila.

Paparan data tersebut menunjukkan bahwa aktualisasi Pancasila dalam undang-undang, khususnya dalam pembentukannya, masih menjadi persoalan besar saat ini. Padahal, dengan kedudukannya sebagai ideologi, dasar negara, dan cita hukum nasional, maka nilai-nilai Pancasila semestinya menjiwai semua undang-undang yang dibentuk. Karena itu penting untuk didiskusikan, bagaimana sebenarnya mekanisme yang berlaku sejauh ini terkait aktualisasi Pancasila dalam pembentukan undang-undang.

Dalam artikel ini, pembahasan aktualisasi Pancasila dalam pembentukan undang-undang diawali dengan uraian pedoman aktualisasi nilai-nilai Pancasila sebagaimana diatur dalam undang-undang yang mengatur pembentukan undang-undang. Uraian ini dimaksudkan untuk mengetahui secara normatif tahapan pembentukan undangundang dan keterkaitannya dengan aktualisasi Pancasila. Pembahasan berikutnya dilanjutkan dengan mekanisme aktualisasi Pancasila sebagai sumber hukum dalam pembentukan undang-undang. Pada bagian ini ditelaah apakah dalam tahapan pembentukan undangundang saat ini telah tersedia mekanisme yang cukup untuk mengaktualisasikan nilai-nilai Pancasila, dan dalam hal belum cukup, apa yang perlu diupayakan. Artikel ditutup dengan pemaparan kesimpulan.

\section{B. Pedoman Aktualisasi Pancasila dalam Pembentukan Undang-undang}

Kebutuhan agar undang-undang yang dibentuk sesuai dengan nilai-nilai yang terkandung dalam Pancasila telah mendapatkan

Pembinaan Ideologi Pancasila, Yogyakarta, 11 November 2020, hlm. 19.

12 Mahkamah Konstitusi Republik Indonesia, "Rekapitulasi Perkara Pengujian Undang-undang", diakses $6 / 2 / 2020$. 
pengaturannya dalam undang-undang mengenai pembentukan undang-undang. Undang-undang tersebut ialah Undang-Undang Nomor 12 Tahun 2011 tentang Pembentukan Peraturan PerundangUndangan, yang beberapa ketentuannya telah diubah dengan Undang-Undang Nomor 15 Tahun 2019. Teknis pembentukan undang-undang juga diatur dalam Peraturan Presiden Nomor 87 Tahun 2014 tentang Peraturan Pelaksana Undang-Undang Nomor 12 Tahun 2011 tentang Pembentukan Peraturan Perundang-undangan, Peraturan Dewan Perwakilan Rakyat (DPR) Nomor 1 Tahun 2014 tentang Tata Tata Tertib DPR RI, dan Peraturan Menteri Hukum dan Hak Asasi Manusia Nomor 20 Tahun 2015 tentang Tata Cara dan Prosedur Pengharmonisan, Pembulatan dan Pemantapan Konsep Rancangan Undang-Undang.

Berdasarkan Undang-Undang Pembentukan Peraturan Perundang-Undangan, pedoman mengaktualisasi nilai-nilai Pancasila dalam peraturan perundang-undangan yang dibentuk setidak terdapat dalam lima bagian. Pertama, Pancasila merupakan sumber dari segala sumber hukum negara. Hal ini diatur pada Pasal 2 Undang-Undang Nomor 12 Tahun 2011. Penjelasan Pasal 2 menegaskan,

"Penempatan Pancasila sebagai sumber dari segala sumber hukum negara adalah sesuai dengan pembukaan Undang-Undang Dasar Negara Republik Indonesia Tahun 1945 alinea keempat yaitu Ketuhanan Yang Maha Esa, Kemanusiaan yang adil dan beradab, Persatuan Indonesia, Kerakyatan yang dipimpin oleh hikmat kebijaksanaan dalam Permusyawaratan/Perwakilan dan Keadilan Sosial bagi seluruh rakyat Indonesia. Menempatkan Pancasila sebagai dasar dan ideologi negara serta sekaligus filosofis negara sehingga setiap materi muatan peraturan perundang-undangan tidak boleh bertentangan dengan nilai-nilai yang terkandung dalam Pancasila".

Kedudukan Pancasila sebagai sumber hukum ini mengharuskan pembentukan undang-undang untuk sesuai dengan nilai-nilai Pancasila. Namun demikian, ketentuan ini masih memiliki kelemahan dalam penjabaran lebih lanjut. Sebagaimana dikatakan Backy Krisnayuda, pembentukan undang-undang belum memberi ruang bagi Pancasila untuk mentrasformasikan dirinya dalam undang-undang yang dibentuk. Ketentuan Pasal 2 tersebut juga terhenti di situ, dan 
tidak ada pengaturan lebih lanjut tentang peran Pancasila dalam pembentukan undang-undang. ${ }^{13}$

Jika dibaca dalam Undang-Undang Nomor 12 Tahun 2011, ruang bagi aktualisasi Pancasila terlihat masih terbatas. Dalam tahapan pembentukan undang-undang misalnya, yang terdiri dari perencanaan, penyusunan, pembahasan, pengesahan atau penetapan, dan pengundangan, ruang bagi aktualisasi Pancasila hanya pada tahapan perencanaan (Pasal 16-23) dan penyusunan pada konteks penyusunan Naskah Akademik, Landasan konsideran menimbang dan kegiatan harminosiasi sebagaimana diatur pada Pasal 43-51. Dengan demikian, pada tahapan pembahasan (Pasal 6771), pengesahan atau penetapan (Pasal 72-74), dan pengundangan (Pasal 81, 90), relatif belum ada ruang untuk mengaktualisasi nilainilai Pancasila.

Kedua, Pancasila sebagai pedoman dalam penyusunan Naskah Akademik. Penyusunan Naskah Akademik, sebagaimana Lampiran I Undang-Undang Nomor 12 Tahun 2011, dapat ditemukan nomenklatur terkait dengan Pancasila yakni pada bagian landasan filosofis. Landasan Filosofis sendiri merupakan "pertimbangan atau alasan yang menggambarkan bahwa peraturan yang dibentuk mempertimbangkan pandangan hidup, kesadaran dan cita hukum yang meliputi suasana kebatinan serta falsafah bangsa Indonesia yang bersumber dari Pancasila dan Pembukaan Undang-Undang Dasar Negara Republik Indonesia Tahun 1945”.

Penjelasan tentang landasan filosofis dari suatu undang-undang yang dibentuk itu menegaskan, pandangan hidup, kesadaran, dan cita hukum yang menjadi pertimbangan dalam membentuk suatu undang-undang, haruslah bersumber dari Pancasila. Hanya saja memang, pengaturan yang demikian itu bersifat umum, dan belum ada indikator dan variabel tentang nilai-nilai Pancasila yang dijadikan tolok ukur dalam penyusunan Naskah Akademik. Oleh karena itu, dalam penyusunan Naskah Akademik belum memiliki tolok ukur,

13 Backy Krisnayuda, Pancasila \& Undang-Undang: Relasi dan Transformasi Keduanya dalam Sistem Ketatanegaraan Indonesia (Jakarta: Kencana, 2016), hlm. 7 . 
indikator dan variabel nilai-nilai Pancasila tersebut. Berkenaan dengan hal ini, dalam berbagai Naskah Akademik Undang-undang, apabila diamati, yang terlihat hanya pencantuman sila tertentu saja dari Pancasila saja, bukan nilai-nilai yang terkandung di dalamnya. Naskah Akademik juga masih dominan menggunakan tolok ukur pasal-pasal dalam Konstitusi UUDNRI 1945. Padahal, dalam UndangUndang Nomor 12 Tahun 2011 disebutkan, Pancasila merupakan merupakan sumber dari segala sumber hukum.

Ketiga, Pengharmonisasian, Pembulatan, dan Pemantapan Konsepsi Rancangan Undang-Undang dalam Kegiatan Penyelarasan Rancangan Undang-Undang. Rumusan nilai-nilai Pancasila pada kegiatan penyelarasan rancangan undang-undang diatur dalam Pasal 51 ayat (4) angka 1 Peraturan Presiden Nomor 87 Tahun 2014, "penghormonisan, pembulatan dan pemantapan konsepsi Rancangan Undang-Undang, dimaksudkan untuk: a. Menyelaraskan Rancangan Undang-Undang dengan: 1. Pancasila, Undang-Undang Dasar Negara Republik Indonesia Tahun 1945, dan Undang-Undang Lainnya”.

Ketentuan tersebut menjelaskan bahwa Pancasila merupakan salah satu dari tolok ukur dalam pengharmonisasian, pembulatan dan pemantapan konsepsi Rancangan Undang-Undang selain UUDNRI 1945 dan undang-undang lainnya. Namun demikian, hal tersebut terputus pada kata Pancasila, tidak ada uraian tentang indikator dan variabel bahwa nilai-nilai Pancasila telah betul-betul diakomodasi.

Dalam konteks yang sama, artikel ini juga menelurusi ketentuan yang terdapat dalam Peraturan DPR Nomor 1 Tahun 2014. Pada peraturan ini, Pancasila dicantumkan dengan menambah rumusan kata "falsafah negara" sebelum kata "Pancasila". Hal ini termuat dalam Pasal 114, "konsepsi dan materi rancangan undang-undang yang disusun oleh DPR, Presiden, atau DPD harus selaras dengan falsafah negara Pancasila dan Undang-Undang Dasar Negara Republik Indonesia Tahun 1945”. Rumusan semacam ini juga masih bersifat umum dengan tanpa menyebutkan indikator dan variabel nilai-nilai Pancasila, sehingga masih perlu ditafsirkan apa saja yang dimaksud falsafah negara Pancasila tersebut. Selain itu, Pancasila dan UUDNRI 1945 diletakkan pada dua hal yang berbeda yakni dengan 
kata hubung "dan". Artinya penyelarasan konsepsi dan materi RUU dengan dua tolok ukur yakni Pancasila dan UUDNRI 1945. Hal ini berarti tidak meletakkan kedudukan pasal-pasal dalam UUDNRI 1945 sebagai penjabaran dari nilai-nilai Pancasila itu sendiri. Oleh karena itu, penting adanya ketegasan terkait indikator dan variabel nilai-nilai Pancasila dalam pengharmonisasian, pembulatan, dan pemantapan konsepsi rancangan undang-undang.

Selain hal di atas, artikel ini juga menelusuri peraturan perundang-undangan yang khusus mengatur terkait dengan pengharmonisasian, pembulatan, dan pemantapan konsepsi rancangan undang-undang yakni Peraturan Menteri Hukum dan HAM Nomor 20 Tahun 2015. Rumusan tentang Pancasila terdapat dalam Pasal 3 huruf a, angka 1, bahwa "Pengharmonisasian Konsepsi Rancangan Peraturan Perundang-undangan dilakukan dengan tujuan untuk: a. menyelaraskan dengan: 1. Pancasila, Undang-Undang Dasar Negara Republik Indonesia Tahun 1945, dan peraturan perundangundangan lain". Rumusan lainnya juga diatur dalam Pasal 10 ayat (3) huruf a, "Analisis konsepsi Rancangan Peraturan Perundangundangan terhadap substansi sebagaimana dimaksud pada ayat (2), dilakukan dengan memperhatikan: a. keterkaitan dan keselarasan substansi dengan Pancasila, Undang-Undang Dasar Negara Republik Indonesia Tahun 1945, dan peraturan perundang-undangan lain”.

Rumusan yang demikian itu mendudukkan Pancasila sebagai tolok ukur dalam penyelerasan substansi rancangan undang-undang. Namun hal ini juga terputus pada kata "Pancasila", tanpa ada indikator dan variabel nilai-nilai Pancasila yang dimaksud. Selain itu, Pancasila dan UUDNRI 1945 sama-sama menjadi tolok ukur dalam pengharmonisan, pembulatan dan pemantapan konsepsi RUU, yang secara tidak langsung berarti menafsirkan Pancasila dan UUDNRI 1945 sebagai dua hal berbeda. Dalam hal ini Pancasila perlu ada penjabaran indikator dan variabel nilai-nilai Pancasila tersebut sebagai tolok ukur, sedangkan UUDNRI 1945 sudah memiliki indikator yang jelas yakni dalam pasal-pasal yang terdapat di dalamnya.

Keempat, Pancasila pada substansi teknik penyusunan peraturan perundang-undangan dalam kegiatan penyelasaran RUU. Dalam 
hal ini, rumusan substansi mengenai Pancasila dapat ditemukan dalam ketentuan terkait teknik penyusunan peraturan perundangundangan. Hal ini diatur dalam Pasal 64 ayat (2) Undang-Undang Nomor 12 Tahun 2011, "teknis penyusunan peraturan perundangundangan tercantum dalam lampiran II yang merupakan bagian tidak terpisahkan dari Undang-Undang ini”. Adapun pencantuman rumusan substansi mengenai Pancasila terdapat dalam lampiran II pada Bab I Kerangka Peraturan Perundang-Undangan, bagian B3 Konsideran poin 19, ${ }^{14}$ "pokok pikiran pada konsideran undangundang memuat unsur filosofis, sosiologis dan yuridis yang menjadi pertimbangan dan alasan pembentuknya yang penulisannya ditempatkan secara berurutan dari filosofis, sosiologis dan yuridis. Dikatakan bahwa "unsur filosofis menggambarkan bahwa peraturan yang dibentuk mempertimbangkan pandangan hidup, kesadaran, dan cita hukum yang meliputi suasana kebatinan serta falsafah bangsa Indonesia yang bersumber dari Pancasila dan Pembukaan UndangUndang Dasar Negara Republik Indonesia Tahun 1945”.

Ketentuan rumusan substansi Pancasila dalam unsur filosofis pada teknis penyusunan undang-undang di atas mencantumkan Pancasila sama dengan ketentuan Pancasila mengenai landasan filosofis dalam Naskah Akademik, yaitu "pandangan hidup, kesadaran, dan cita hukum yang meliputi suasana kebatinan serta falsafah bangsa Indonesia yang bersumber dari Pancasila”. Selain itu, Pancasila dan Pembukaan UUDNRI 1945 memiliki kedudukan yang sama sebagai sumber dari unsur filosofis, dengan kata penghubung "dan". Ini artinya terdapat dua sumber pandangan hidup, kesadaran, dan cita hukum yang meliputi suasana kebatinan serta falsafah bangsa, yakni Pancasila dan Pembukaan UUDNRI 1945. Pada konteks ini juga tidak ada penjelasan tentang indikator dan variabel nilai-nilai Pancasila sebagai tolok ukur dalam penyusunan unsur filosofis tersebut.

Kelima, Pancasila dalam asas-asas materi muatan undangundang. Pasal 2 Undang-Undang Nomor 12 Tahun 2011 mengatur,

14 Lampiran II Undang-Undang Nomor 12 Tahun 2011 tentang Pembentukan Peraturan Perundang-undangan: Teknis Penyusunan Peraturan PerundangUndangan. 
"Pancasila merupakan sumber dari segala sumber hukum". Penjelasan Pasal ini hanya menjelaskan Pancasila secara umum tanpa memerinci indikator atau variabel nilai-nilai yang terkandung di dalamnya yang dijadikan sebagai pedoman dalam pembentukan undang-undang. Berkenaan dengan hal ini, tafsir yurdis oleh BPHN menyatakan bahwa indikator dan variabel sebagai penjabaran nilai-nilai Pancasila terdapat dalam Pasal 6 ayat (1) mengenai asas-asas materi muatan peraturan perundang-undangan. Hal ini dapat ditemukan dalam evaluasi hukum yang dilakukan BPHN, "Pasal 2 Pancasila merupakan sumber dari segala sumber hukum negara, pasal ini dijabarkan lebih jauh dalam Pasal 6 ayat (1)". ${ }^{15}$ Artikel ini sependapat bahwa Pasal 6 ayat (1) merupakan penegasan dari jiwa Pancasila, yang berarti tidak perlu ada lagi penafsiran atas indikator nilai-nilai setiap sila sila Pancasila. Namun demikian, dalam praktiknya penafsiran indikator nilai-nilai Pancasila dan variabel asas-asas materi muatan ini juga dirumuskan oleh lembaga BPHN dan BPIP melalui keputusannya, bukan melalui undang-undang. Oleh karena itu, maka secara yuridis perlu ada penegasan dalam undang-undang yang mengatur tentang pembentukan undang-undang mengenai kedua hal tersebut, yakni rumusan indikator nilai-nilai Pancasila dan variabel asas-asas materi muatan sebagai pedoman dalam pembentukan undang-undang.

Ketentuan Pasal 6 ayat (1) mengenai asas materi muatan peraturan perundang-undangan menegaskan, terdapat 10 poin, yakni pengayoman; kemanusiaan; kekeluargaan; kenusantaraan; bhineka tunggal ika; keadilan; kesamaan kedudukan dalam hukum dan pemerintahan; ketertiban dan kepastian hukum dan/atau keseimbangan; keserasian; dan keselarasan. Apabila diperhatikan asas materi muatan tersebut, belum ada memasukkan asas Ketuhanan Yang Maha Esa. Hal ini juga diakui oleh BPHN dalam hasil evaluasi hukum undang-undang terhadap nilai-nilai Pancasila, yang menyatakan "Perlu ditambahkan asas "Ketuhanan Yang Maha Esa" dalam Pasal 6 ayat (1). Hal ini sebagai konsekuensi dari Pasal 29 ayat (1) UUD 1945 "Negara berdasar atas Ketuhanan Yang Maha Esa" dan

15 BPHN, "Laporan Akhir Kelompok Kerja Analisis”, hlm. 113. 
Pasal 2 Undang-Undang Nomor 12 Tahun 2011 "Pancasila merupakan sumber segala sumber hukum negara”. Dengan demikian, Pasal 6 ini seharusnya fokus pada penjabaran ketentuan tentang Pancasila sebagai sumber segala sumber hukum negara. ${ }^{16}$ Berkenaan asas materi muatan ini juga terdapat kelemahan mengenai ketegasan norma atas ketatan pembentukan undang-undang pada asas materi muatan. Hal tersebut dapat ditemukan dari evaluasi BPHN pada Undang-Undang Nomor 12 Tahun 2011, yang menyatakan 'kata 'mencerminkan' pada frasa 'materi muatan peraturan perundang-undangan harus mencerminkan asas' sebaiknya diganti dengan frasa 'materi muatan peraturan perundang-undangan tidak boleh bertentangan dengan asas"”. Hal ini untuk mempermudah deteksi ketentuan dari PUU yang tidak memenuhi asas-asas yang merupakan penjabaran dari nilai-nilai Pancasila, dalam analisis dan evaluasi terhadap seluruh PUU”. ${ }^{17}$

Berdasarkan uraian di atas, maka ketentuan yang belum diatur tersebut perlu perlu dimasukkan ke dalam undang-undang yang mengatur pembentukan undang-undang dengan melakukan perubahan atas Undang-Undang Nomor 12 Tahun 2011 dan UndangUndang Nomor 15 Tahun 2019. Berkenaan dengan hal ini, BPHN juga merekomendasikan, Undang-Undang Nomor 12 Tahun 2011 yang telah diubah dengan Undang-Undang Nomor 15 Tahun 2019 termasuk kategori undang-undang yang mendesak untuk dilakukan perubahan". ${ }^{18}$

Berdasarkan uraian terkait rumusan substansinilai-nilai Pancasila yang dicantumkan dalam peraturan perundang-undangan yang mengatur terkait tahapan pembentukan undang-undang ternyata diketahui bahwa rumusan yang mengatur perihal Pancasila sebagai pedoman dalam pembentukan undang-undang pada kegiatan di setiap tahapan pembentukan undang-undang meletakkan nilai-nilai Pancasila pada sila-sila Pancasila itu sendiri. Pada konteks ini, belum ada rumusan pasal yang menegaskan terkait dengan indikator dan

16 BPHN, "Laporan Akhir Kelompok Kerja Analisis”, hlm. 115.

17 BPHN, "Laporan Akhir Kelompok Kerja Analisis”, hlm. 115.

18 BPHN, "Laporan Akhir Kelompok Kerja Analisis”, hlm. 167. 
Tabel 1. Rumusan terkait Pancasila dalam pembentukan undang-undang

\begin{tabular}{|c|c|c|}
\hline Dasar Hukum & Ketentuan & Rumusan \\
\hline \multirow{5}{*}{$\begin{array}{l}\text { Undang-Undang } \\
\text { Nomor } 12 \\
\text { Tahun } 2011\end{array}$} & $\begin{array}{l}\text { Lampiran I, Bab IV, Bagian } \\
\text { A mengenai Landasan } \\
\text { Filosofis Naskah Akademik }\end{array}$ & $\begin{array}{l}\text { "bersumber dari Pancasila } \\
\text { dan pembukaan Undang- } \\
\text { Undang Dasar Negara } \\
\text { Republik Indonesia Tahun } \\
\text { 1945". }\end{array}$ \\
\hline & $\begin{array}{l}\text { Lampiran II, Bab I, Bagian } \\
\text { B 3, Point ke } 19 \text { mengenai }\end{array}$ & $\begin{array}{l}\text { "bersumber dari Pancasila } \\
\text { dan Pembukaan Undang- }\end{array}$ \\
\hline & Unsur Filosofis Konsideran & Undang Dasar Negara \\
\hline & Menimbang & $\begin{array}{l}\text { Republik Indonesia Tahun } \\
\text { 1945" }\end{array}$ \\
\hline & $\begin{array}{l}\text { Pasal } 51 \text { ayat (4) } \\
\text { angka } 1 \text { mengenai } \\
\text { penghormonisan, } \\
\text { pembulatan dan } \\
\text { pemantapan konsepsi } \\
\text { Rancangan Undang- } \\
\text { Undang. }\end{array}$ & $\begin{array}{l}\text { "Menyelaraskan Rancangan } \\
\text { Undang-Undang dengan: } 1 . \\
\text { Pancasila, Undang-Undang } \\
\text { Dasar Negara Republik } \\
\text { Indonesia Tahun 1945, dan } \\
\text { Undang-Undang Lainnya”. }\end{array}$ \\
\hline $\begin{array}{l}\text { Peraturan } \\
\text { Presiden Nomor } \\
87 \text { Tahun } 2014\end{array}$ & $\begin{array}{l}\text { Pasal } 8 \text { ayat (3) mengenai } \\
\text { penghormonisan, } \\
\text { pembulatan dan } \\
\text { pemantapan konsepsi } \\
\text { Rancangan Undang- } \\
\text { Undang }\end{array}$ & $\begin{array}{l}\text { "Menyelaraskan Rancangan } \\
\text { Undang-Undang dengan: } 1 . \\
\text { Pancasila, Undang-Undang } \\
\text { Dasar Negara Republik } \\
\text { Indonesia Tahun 1945, dan } \\
\text { Undang-Undang Lainnya”. }\end{array}$ \\
\hline $\begin{array}{l}\text { Peraturan DPR } \\
\text { Nomor } 1 \text { Tahun } \\
2014\end{array}$ & $\begin{array}{l}\text { Pasal } 144 \text { mengenai } \\
\text { konsepsi dan materi } \\
\text { rancangan undang-undang }\end{array}$ & $\begin{array}{l}\text { "selaras dengan falsafah } \\
\text { negara Pancasila dan } \\
\text { Undang-Undang Dasar } \\
\text { Negara Republik Indonesia } \\
\text { Tahun } 1945\end{array}$ \\
\hline \multirow[t]{2}{*}{$\begin{array}{l}\text { Peraturan } \\
\text { Menteri Hukum } \\
\text { dan Hak Asasi } \\
\text { Manusia Nomor } \\
20 \text { Tahun } 2015\end{array}$} & $\begin{array}{l}\text { Pasal 3, huruf a. } \\
\text { angka } 1 \text { mengenai } \\
\text { Pengharmonisasian } \\
\text { Konsepsi Rancangan } \\
\text { Peraturan Perundang- } \\
\text { undangan. }\end{array}$ & $\begin{array}{l}\text { "menyelaraskan dengan: } 1 . \\
\text { Pancasila, Undang-Undang } \\
\text { Dasar Negara Republik } \\
\text { Indonesia Tahun } 1945, \\
\text { dan peraturan perundang- } \\
\text { undangan lain". }\end{array}$ \\
\hline & $\begin{array}{l}\text { Pasal } 10 \text { ayat (3) huruf a } \\
\text { mengenai analisis konsepsi } \\
\text { Rancangan Peraturan } \\
\text { Perundang-undangan. }\end{array}$ & $\begin{array}{l}\text { "keterkaitan dan keselarasan } \\
\text { substansi dengan Pancasila, } \\
\text { Undang-Undang Dasar } \\
\text { Negara Republik Indonesia } \\
\text { Tahun 1945, dan peraturan } \\
\text { perundang-undangan lain". }\end{array}$ \\
\hline
\end{tabular}


variabel nilai-nilai Pancasila sebagai pedoman dan tolok ukur dalam mengaktualkan nilai-nilai Pancasila ke dalam undang-undang yang diatur dalam undang-undang tentang pembentukan undang-undang. Pada konteks ini ketentuan yang mengatur tentang pembentukan undang-undang yang menegaskan Pancasila merupakan salah satu pedoman dan tolok ukur dalam pembentukan undang-undang sebagai sumber dari segala sumber hukum bukan UUDNRI 1945. Ketentuan tersebut dapat dilihat pada Tabel 1.

Berdasarkan Tabel 1 dapat dipahami bahwa rumusan Pancasila sebagai sumber hukum mempunyai dua fungsi. Pertama, sebagai landasan atau unsur filosofis dalam Naskah Akademik dan konsideran menimbang undang-undang. Kedua, sebagai tolok ukur atau pedoman dalam penyelarasan atau penyesuaian substansi dalam rancangan undang-undang dengan nilai-nilai yang diakui oleh bangsa Indonesia yang termuat dalam Pancasila. Hal ini berarti aktualisasi nilai-nilai Pancasila ke dalam undang-undang berpedoman dan menggunakan tolok ukur pada nilai-nilai Pancasila itu sendiri, selain pasal-pasal dalam UUDNRI 1945. Namun demikian, dalam UndangUndang Nomor 12 Tahun 2011 dan Undang-undang Nomor 15 tahun 2019 belum ada pengaturan mengenai indikator dan variabel nilainilai Pancasila sebagai pedoman dan tolok ukur dalam pembentukan undang-undang.

Sementara itu, ketika undang-undang selesai dibentuk dan kemudian dilakukan evaluasi dan pengujian, misalnya melalui kajian BPHN dan BPIP, justru digunakan indikator dan variabel nilainilai Pancasila sebagai tolok ukurnya. Indikator dan variabel nilainilai Pancasila yang digunakan oleh BPHN diatur dalam Pedoman Analisis dan Evaluasi Hukum Nomor PHN-01.HN.01.03 Tahun 2019, sebagaimana terlihat pada Tabel 2.

Selain BPHN, BPIPjuga merumuskan indikator dan variabelnilainilai Pancasila yang digunakan sebagai analisis, evaluasi, pengujian, dan rekomendasi atas kesesuaian undang-undang dengan nilai-nilai Pancasila. Hal ini sebagaimana dituangkan dalam Keputusan Deputi Bidang Hukum, Advokasi dan Pengawasan Regulasi BPIP Nomor 1 Tahun 2020 tentang Petunjuk Teknis Penyelarasan, Pengkajian 
Tabel 2. Indikator nilai Pancasila oleh BPHN

\begin{tabular}{|c|c|}
\hline Sila & Nilai-nilai Jabaran \\
\hline $\begin{array}{l}\text { Ketuhanan } \\
\text { Yang Maha Esa }\end{array}$ & $\begin{array}{l}\text { - Hanya mengakui keberadaan pemeluk agama (percaya dan takwa } \\
\text { kepada Tuhan YME) atau penganut kepercayaan, tidak mengakui } \\
\text { penganut atheis; } \\
\text { - Adanya jaminan penghormatan bagi kepentingan masing-masing } \\
\text { pemeluk agama dan penganut kepercayaan; } \\
\text { - Adanya jaminan tidak ada pemaksanaan atas suatu agama atau keper- } \\
\text { cayaan; } \\
\text { - Mengedepankan prinsip kebenaran, keadilan, kebaikan, kejujuran, } \\
\text { persaudaraan, kesucian, keindahan (tidak ditemukan kandungan nilai } \\
\text { yang menegasikan prinsi-prinsip tersebut). }\end{array}$ \\
\hline $\begin{array}{l}\text { Kemanusiaan } \\
\text { yang adil dan } \\
\text { beradab }\end{array}$ & $\begin{array}{l}\text { - Adanya pengakuan persamaan derajat, hak dan kewajiban sesama } \\
\text { warga Negara (tidak ditemukan kandungan nilai yang menegasikan } \\
\text { persamaan derajat, hak dan kewajiban sesama warga Negara); } \\
\text { - Adanya jaminan terhadap pemajuan HAM(tidak ditemukan kandungan } \\
\text { nilai yang menegasikan pemajuan HAM); } \\
\text { - Adanya jaminan terhadap pemajuan sikap tenggang rasa (tidak dite- } \\
\text { mukan kandungan nilai yang menegasikan sikap tenggang rasa); } \\
\text { - Adanya jaminan terhadap pemajuan saling menghormati dan kerja } \\
\text { sama dengan bangsa lain (tidak ditemukan kandungan nilai yang } \\
\text { menegasikan saling menghormati dan kerjasama dengan bangsa lain). }\end{array}$ \\
\hline $\begin{array}{l}\text { Persatuan } \\
\text { Indonesia }\end{array}$ & $\begin{array}{l}\text { - Adanya jaminan penempatan persatuan, kesatuan, keselamatan bangsa } \\
\text { dan Negara di atas kepentingan pribadi dan golongan; } \\
\text { - Terkandung nilai yang mengembangkan rasa cinta tanah air dan } \\
\text { bangsa (tidak ditemukan kandungan nilai yang menegasikan rasa cinta } \\
\text { tanah air dan bangsa); } \\
\text { - Terkandung semangat dalam rangka memelihara ketertiban dunia } \\
\text { yang berdasarkan kemerdekaan, perdamaian abadi dan keadilan } \\
\text { sosial; } \\
\text { - Terkandung nilai persatuan Indonesia dan Bhineka Tunggal Ika. }\end{array}$ \\
\hline $\begin{array}{l}\text { Kerakyatan } \\
\text { yang dipimpin } \\
\text { oleh hikmat } \\
\text { kebijaksanaan } \\
\text { dalam permu- } \\
\text { syawaratan/ } \\
\text { perwakilan }\end{array}$ & $\begin{array}{l}\text { - Mengandung keseimbangan antara hak dan kewajiban; } \\
\text { - Mengandung nilai yang mengutamakan musyawarah dalam meng- } \\
\text { ambil keputusan, untuk hal yang menyangkut kehidupan bersama; } \\
\text { - Mengandung nilai yang mewajibkan tanggung jawab atas keputusan/ } \\
\text { hasil musyawarah; } \\
\text { - Mengandung nilai yang mewajibkan tanggung jawab dalam pelaksa- } \\
\text { naan tugas dan jabatan. }\end{array}$ \\
\hline $\begin{array}{l}\text { keadilan sosial } \\
\text { bagi seluruh } \\
\text { Indonesia }\end{array}$ & $\begin{array}{l}\text { - Mengandung nilai yang memajukan usaha bersama dan semangat } \\
\text { saling menolong; } \\
\text { - Tidak mengandung nilai yang berimplikasi pada pelegalan kegiatan } \\
\text { yang bersifat pemerasan terhadap orang lain; } \\
\text { - Mengandung nilai yang mengedepankan sikap seimbang, (tidak berle- } \\
\text { bihan) terhadap harta yang dimiliki; } \\
\text { - Tidak mengandung nilai yang dapat melegalkan penggunaan hak } \\
\text { milik untuk hal-hal yang bertentangan dengan kepentingan umum/ } \\
\text { kepentingan bersama. }\end{array}$ \\
\hline
\end{tabular}


Tabel 3. Indikator nilai Pancasila oleh BPIP

\begin{tabular}{ll}
\hline \multicolumn{1}{c}{ Sila } & \multicolumn{1}{c}{ Nilai-nilai Jabaran } \\
\hline Ketuhanan Yang & Peraturan perundang-undangan yang dibentuk harus memberikan \\
perlindungan dan penghoramatan kepada setiap orang untuk & percaya dan taqwa kepada Tuhan yang Maha Esa sesuai dengan \\
& agama atau kepercayaan secara berkeadaban. \\
& - Peraturan perundang-undangan menjamin bahwa bangsa Indonesia \\
& adalah bangsa yang mengakui adanya Tuhan Yang Maha Esa; \\
& - Peraturan perundang-undangan menjamin bahwa setiap warga \\
& negara dapat mengamalkan ajaran agama dan kepercayaannya; \\
& - Peraturan perundang-undangan menjamin kebebasan dan penghor- \\
& matan bagi tiap-tiap pemeluk agama dan penganut kepercayaan untuk \\
& beribadah melaksanakan kewajiban agama dan kepercayaannya; \\
& - Peraturan perundang-undangan menjamin setiap orang dalam menja- \\
& lankan perintah agama dan kepercayaannya selaras dengan kehidupan \\
& bermasyarakat, berbangsa dan bernegara; \\
& - Peraturan perundang-undangan menjamin penghormatan kepada \\
& setiap orang untuk memeluk agama dan kepercayaannya. \\
& Peraturan perundang-undangan yang dibentuk harus memberikan
\end{tabular}

Kemanusiaan yang adil dan beradab
Persatuan Indonesia
Peraturan perundang-undangan yang dibentuk harus memberikan pengakuan persamaan derajat, persamaan hak dan persamaaan kewajiban antar sesama manusia.

- Peraturan perundang-undangan menjamin kemerdekaan, kedaulatan, persatuan dan kesatuan bangsa serta kesetaraan hubungan antar bangsa-bangsa di dunia;

- Peraturan perundang-undangan menjamin hubungan antar bangsa dengan mengutamakan kepentingan nasional;

- Peraturan perundang-undangan menjunjung tinggi hak asasi manusia yang bersifat universal dengan tetap mengingat kearifan bangsa dan menjaga hubungan antar bangsa yang sederajat, berkeadilan dan kerkeadaban;

- Peraturan perundang-undangan mencerminkan pengakuan dan kesederajatan manusia sesuai dengan harkat dan martabatnya sebagai makhluk Tuhan Yang Maha Esa;

- Peraturan Perundang-undangan berfungsi mengembangkan sikap saling menghargai dan menghormati terhadap perbedaan suku, agama, kepercayaan, ras dan antar golongan.

Peraturan perundang-undangan yang dibentuk harus mampu menumbuhkan rasa setiap orang memiliki dan mencintai Tanah Air, bersedia melindungi segenap bangsa dan seluruh tumpah darah Indonesia.

- Peraturan perundang-undangan menjamin persatuan bangsa, keutuhan dan kesatuan wilayah NKRI serta mengembangkan kebudayaan;

- Peraturan perundang-undangan menguatkan semangat kebangsaan yang melindungi segenap bangsa dan seluruh tumpah darah Indonesia dalam bingkai NKRI;

- Peraturan perundang-undangan menjamin bahwa setiap warga negara mengutamakan kepentingan bangsa dan negara di atas kepentingan pribadi dan golongan; 


\begin{tabular}{ll}
\hline Persatuan & - \\
Indonesia & reraturan perundang-undangan berfungsi untuk mengembangkan \\
(lanjutan) & bangsa dan negara bagi setiap warga negara; \\
& - Peraturan perundang-undangan mampu menumbuhkan semangat \\
& gotong royong, rasa kebanggaan berbangsa dan bertanah air Indo- \\
& nesia.
\end{tabular}

Kerakyatan yang dipimpin oleh hikmat kebijaksanaan dalam permusyawaratan/ perwakilan
Peraturan perundang-undangan yang dibentuk harus dapat mendorong dan memberikan penghormatan terhadap aspirasi dan kepentingan rakyat dalam politik dan terus menyempurnakan sistem dan praktek demokrasi.

- Peraturan perundang-undangan senantiasa memperhatikan bahwa Negara Indonesia bukan sebuah negara yang didirikan untuk satu golongan tetapi untuk semua yang bertanah air Indonesia dengan berdasarkan penyelenggaraan negara pada permusyawaratan perwakilan;

- Peraturanperundang-undanganmemperhatikanhikmatkebijaksanaan dalam permusyawaratan perwakilan yang didasarkan pada nilai-nilai ketuhanan, kemanusiaan, persatuan dan keadilan sosial bagi seluruh rakyat Indonesia;

- Peraturan perundang-undangan menjamin bahwa demokrasi Indonesia berdasarkan permusyawaratan yang mampu mewujudkan kesejahteraan sosial;

- Peraturan perundang-undangan menjamin setiap warga negara menghormati dan menjunjung tingggi setiap keputuasan yang dihasilkan berdasarkan musyawarah/mufakat dan melaksanakan keputusan tersebut dengan iktikad baik dan rasa tanggung jawab;

- Peraturan perundang-undangan harus menjamin terselenggaranya demokrasi politik yang berkeadaban dan berkeadilan.

Keadilan sosial bagi seluruh Indonesia
Peraturan perundang-undangan yang dibentuk harus mampu mendorong pengembangan usaha bersama dengan semangat tolong menolong.

- Peraturan perundang-undangan berfungsi mewujudkan keadilan dan kesejahteraan bagi seluruh rakyat Indonesia baik lahir maupun batin;

- Peraturan perundang-undangan menjamin perlindungan kepada setiap orang untuk menghargai proses cipta, karya dan karsa secara bertanggungjawab demi terwujudnya kesejahteraan rakyat;

- Peraturan perundang-undangan menjamin hak setiap warga negara untuk memperoleh pendidikan, kesehatan, pekerjaan dan kesempatan berusaha serta penghidupan yang layak;

- Peraturan perundang-undangan yang dibentuk menumbuhkan kemandirian ekonomi masyarakat dan kesejahteraan rakyat yang berkeadilan;

- Peraturan perundang-undangan menjamin kegiatan perekonomian yang berkeadilan, berdaya saing, berwawasan lingkungan dan menjaga keseimbangan kemajuan dan kesatuan ekonomi nasional. 
Analisis dan Rekomendasi di Kedeputian bidang hukum, Advokasi dan Pengawasan Regulasi, pada 21 Februari 2020, pada Lampiran III. Rumusan oleh BPIP ini dapat dilihat pada Tabel 3.

Rumusan nilai-nilai setiap sila-sila Pancasila tersebut di atas digunakan oleh BPHN dan BPIP dalam melakukan penyelarasan, pengkajian, analisis, dan rekomendasi terhadap undang-undang yang sudah diundangkan. Artikel ini berpendapat, penyelerasan suatu undang-undang yang dibentuk dengan nilai-nilai Pancasila dengan indikator semacam itu bukan saja pada tahap evaluasi atau pengujiannya, melainkan sudah seharusnya pada tahapan pembentukannya. Hal ini didasari alasan bahwa Pancasila merupakan cita hukum (rechtsidee) dan sumber hukum sehingga nilai-nilai yang terkandung di dalamnya harus diaktualisasi ke dalam undang-undang yang dibentuk.

Berkaitan dengan cita hukum tersebut, Teguh Prasetyo dan Arie Purnomosi mengatakan, Pancasila merupakan suatu asas kerohanian yang meliputi suasana kebatinan atau cita-cita hukum, sehingga merupakan suatu sumber nilai, norma serta kaidah, baik moral maupun hukum negara dan menguasai hukum dasar baik tertulis maupun tidak tertulis. Dalam kedudukannya sebagai cita hukum, maka Pancasila mempunyai kekuatan hukum mengikat. ${ }^{19}$ Jawahir Thontowi juga mengatakan, Pancasila merpakan kaidah penilai, ukuran, dan batu uji (norma kritik) yang bersifat etis-filisofis, disebabkan nilai-nilai yang terkandung di dalamnya secara substantif sangat kental dengan karakter nilai-nilai filosofis. ${ }^{20}$ Sementara itu, Becky Krisnayuda mengatakan, nilai-nilai dasar yang terkandung dalam Pembukaan UUDNRI 1945 memerlukan penjabaran lebih lanjut sehingga dapat menjadi nilai instrumental. ${ }^{21}$

Berdasarkan uraian di atas, maka menjadi penting dalam undang-undang yang mengatur tentang pembentukan undang-

19 Teguh Prasetyo dan Arie Purnomosidi, Membangun Hukum Berdasarkan Pancasila (Bandung: Nusa Media, 2014), hlm. 35.

20 Jawahir Thontowi, Pancasila dalam Perspektif Hukum: Pandangan terhadap Ancaman the Lost Generation (Yogyakarta: UII Press, 2016), hlm. 78.

21 Krisnayuda, Pancasila \& Undang-Undang, hlm. 12. 
undang untuk secara tegas menjabarkan rumusan indikator dan variabel nilai-nilai Pancasila yang dapat dijadikan pedoman dalam pembentukan undang-undang. Terlebih lagi Pancasila dalam hal ini menjadi sumber dari segala sumber hukum, yang megandung konsekuensi bahwa kekuasaan atau kedaulatan hukum bersumber pada Pancasila. Oleh sebab itu, setiap hukum yang lahir harus berdasar pada Pancasila dengan memuat konsistensi isi mulai dari yang paling atas hierarkinya sampai yang paling rendah. ${ }^{22}$ Dengan dirumuskan dan dipahaminya Pancasila sebagai cita hukum, maka akan memudahkan penjabarannya ke dalam berbagai perangkat aturan kewenangan dan aturan perilaku, dan memudahkan pula terjaganya konsistensi dalam penyelenggaraan hukum”. ${ }^{23}$

Ketiadaan indikator dan variabel nilai-nilai Pancasila yang dijadikan pedoman dan tolok ukur dalam pembentukan undangundang sejauh ini berakibat pada adanya undang-undang yang secara eksplisit mencantumkan Pancasila, namun juga ada yang tidak. Hal ini dapat ditemukan dari data Rancangan Undang-Undang Program Legislasi Nasional Jangka Menengah Usulan Pemerintah Tahun 20152019 yang berjumlah 84. Dari jumlah tersebut, hanya enam yang mencantumkan Pancasila sebagai latar belakangnya, yakni RUU Kitab Undang-Undang Hukum Pidana, RUU Sistem Pendidikan Nasional, RUU Hukum Acara Pidana, RUU Perkumpulan, RUU Persandian, dan RUU Balai Harta Peninggalan. Sementara itu, 78 lainnya, tidak menggunakan Pancasila namun menggunakan pasal-pasal dalam UUDNRI 1945. Padahal sebagai sumber dari segala sumber hukum, Pancasila harus menjadi rujukan utama dalam semua jenis peraturan perundang-undangan termasuk Undang-Undang. Walaupun secara hierarki Undang-Undang harus tunduk pada ketentuan dalam UUDNRI 1945, namun sebagai sumber hukum dan cita hukum, pembentukan Undang-undang juga harus taat dengan nilai-nilai

22 Ni'matul Huda, "Kesesuaian Materi Muatan dalam Peraturan PerundangUndangan dengan Nilai Pancasila”, makalah dalam Seminar dan Presentasi Kajian, Analisis dan Rekomendasi Peraturan Perundang-Undangan Tahun 2020, diselenggarakan Badan Pembinaan Ideologi Pancasila, Yogyakarta, 12 November 2020, hlm. 6.

23 Huda, “Kesesuaian Materi Muatan dalam Peraturan”, hlm. 4. 
Pancasila yang tercantum dalam alinea keempat Pembukaan UUDNRI 1945.

Uraian di atas memberi pemahaman bahwa adanya indikator dan variabel nilai nilai Pancasila akan memberikan ketegasan kedudukan Pancasila sebagai sumber dari segala sumber hukum dan cita hukum. Hal ini penting, mengingat dalam sejarah ketatanegaraan Republik Indonesia, Pancasila selalu saja ditafsiran beragam oleh masing-masing rezim berkuasa. Heri Herdiantom, Fokky Fuad Wasitaatmadja, dan Jumanta Hamdayana misalnya, mengidentifikasi perbedaan penafsiran itu dalam tiga era rezim keuasaan. Pertama, pada masa Orde Lama (5/7/1959-11/3/1966), yang menfasrikan Pancasila dengan Nasakom (Nasionalis-Agama-Komunis), yang kemudian disebut trisila, bahkan kemudian bisa diperas menjadi ekasila (gotong royong). Kedua, pada masa Orde Baru (11/3/1966-21/ 5 / 1998), yang menfasrikan Pancasila ke dalam butir-butir pedoman yang ditetapkan oleh Majelis Permusyawaratan Rakyat, yaitu Pedoman Penghayatan dan Pengamalan Pancasila, atau lebih dikenal P4. Ketiga, pada Masa Reformasi (21 / 5 / 1998-sekarang), yang menegaskan Pancasila sebagai dasar negara, yang mengandung makna ideologi nasional sebagai cita-cita dan tujuan negara. ${ }^{24}$

Dengan demikian, untuk mewujudkan undang-undang yang selaras dan sesuai dengan nilai-nilai Pancasila, maka nilai-nilai Pancasila perlu ditafsirkan secara rinci. Perincian ini akan menjadi indikator, variabel, dan tolok ukur nilai-nilai Pancasila sebagai sumber dari segala sumber hukum negara, sehingga undang-undang yang dibentuk akan dapat dikatakan sebagai bagian dari aktualisasi Pancasila. Agar mempunyai kekuatan hukum, maka rumusan indikator dan variabel nilai-nilai Pancasila tersebut sebaiknya dimuat dalam undang-undang yang mengatur tentang pembentukan undang-undang.

Artikel ini berpendapat, indikator dan variabel nilai-nilai Pancasila tersebut untuk saat ini dapat menggunakan indikator dan variabel yang telah dirumuskan oleh BPHN dan BPIP. Bahkan,

24 Heri Hardiawanto, Fokky Fuad Wasitaatmadja, dan Jumanta Hamdayana, Spritualisme Pancasila (Jakarta: Prenada Media Group, 2018), hlm. xiii. 
rumusan kedua lembaga tersebut juga telah banyak digunakan sejauh ini untuk mengevaluasi undang-undang yang dibentuk. Dengan diatur dalam undang-undang, maka indikator dan variabel ini ke depannya diharapkan tidak lagi tersebar dalam beragam aturan di luar undang-undang. Keberlakuannya juga dengan begitu tidak hanya dalam evaluasi dan pengujian undang-undang yang telah diundangkan, melainkan pula berlaku pada tahapan pembentukan undang-undang.

\section{Mekanisme Aktualisasi Pancasila sebagai Sumber Hukum dalam Pembentukan Undang-undang}

Uraian sebelumnya menunjukkan masih adanya undang-undang yang tidak sesuai dengan nilai-nilai Pancasila setelah diundangkan, salah satunya disebabkan masih belum kuatnya pengaturan Pancasila sebagai pedoman dalam pembentukan undang-undang. Oleh karena itu diperlukan adanya konsep penguatan dalam mengaktualisasi nilai-nilai Pancasila pada tahapan pembentukan undang-undang.

Undang-Undang Nomor 15 Tahun 2019 telah memberikan ruang dalam penguatan tersebut melalui peninjauan dan pemantauan terhadap undang-undang yang telah dibentu. Hasil peninjauan dan pemantauan ini selanjutnya dapat dijadikan sebagai usulan dalam penyusunan prolegnas. Berkenaan dengan peninjauan dan pemantauan ini, dalam praktiknya dilakukan oleh pemerintah melalui BPHN dan BPIP, dengan cara melakukan analisis, evaluasi dan pengujian undang-undang terhadap nilai-nilai Pancasila. Uraian berikut akan menelaah penijauan dan pemantauan oleh kedua lembaga tersebut.

Pertama, analisis dan evaluasi oleh BPHN. Kegiatan ini diatur dalam Pedoman Analisis dan Evaluasi Hukum Nomor PHN-01. HN.01.03 Tahun 2019. BPHN di sini menetapkan tolok ukur dalam analisis dan evaluasi yakni berupa rumusan rincian indikator nilainilai Pancasila, sebagaimana telah diruaikan sebelumnya dalam Tabel 2. Adapun variabel yang digunakan dalam analisis dan evaluasi hukum, selain nilai-nilai Pancasila, adalah materi muatan undang- 
undang. Di sana terdapat 10 variabel penilaian pemenuhan nilainilai Pancasila, ${ }^{25}$ yang dapat digunakan secara kumulatif ataupun alternatif, disesuaikan dengan area substansi dari suatu peraturan perundang-undangan. Semakin peraturan perundang-undangan tersebut mengatur ke arah moralitas maka asas yang digunakan semakin komprehensif.

Variabel tersebut adalah, pertama, pengayoman, yaitu keharusan setiap materi muatan peraturan perundang-undangan berfungsi memberikan perlindungan untuk menciptakan ketentraman masyarakat. Kedua, kemanusiaan, yaitu keharusan setiap materi muatan peraturan perundang-undangan mencerminkan pelindungan dan penghormatan hak asasi manusia serta harkat dan martabat setiap warga negara dan penduduk Indonesia secara proporsional. Ketiga, kebangsaan, yaitu keharusan setiap materi muatan peraturan perundang-undangan mencerminkan sifat dan watak bangsa Indonesia yang majemuk dengan tetap menjaga prinsip Negara Kesatuan Republik Indonesia. Keempat, kekeluargaan, yaitu keharusan setiap materi muatan peraturan perundang-undangan mencerminkan musyawarah untuk mencapai mufakat dalam setiap pengambilan keputusan.

Kelima, kenusantaraan, yaitu keharusan setiap materi muatan peraturan perundang-undangan senantiasa memperhatikan kepentingan seluruh wilayah Indonesia dan materi muatan peraturan perundang-undangan yang dibuat di daerah merupakan bagian dari sistem hukum nasional yang berdasarkan Pancasila dan UUD NRI Tahun 1945. Keenam, Bhineka tunggal Ika, yaitu keharusan setiap materi muatan peraturan perundang-undangan memperhatikan keragaman penduduk, agama, suku dan golongan, kondisi khusus daerah serta budaya dalam kehidupan bermasyarakat, berbangsa, dan bernegara. Ketujuh, keadilan, yaitu keharusan setiap materi muatan

25 Badan Pembinaan Hukum Nasional Kementerian Hukum dan Hak Asasi Manusia Republik Indonesia, "Pedoman Analisis dan Evaluasi Hukum Nomor PHN-01.HN.01.03 Tahun 2019”, https://www.bphn.go.id/data/ documents/pedoman_aeh_no_phn-01.hn.01.03_tahun_2019.pdf, hlm.1314. 
peraturan perundang-undangan harus mencerminkan keadilan secara proporsional bagi setiap warga negara. Kedelapan, kesamaan kedudukan dalam hukum dan pemerintahan, yaitu keharusan setiap materi muatan peraturan perundang-undangan tidak boleh memuat hal yang bersifat diskriminatif berdasarkan latar belakang, antara lain, agama, suku, ras, golongan, gender, atau status sosial. Kesembilan, ketertiban dan kepastian hukum, yaitu keharusan setiap materi muatan peraturan perundang-undangan dapat mewujudkan ketertiban dalam masyarakat melalui jaminan kepastian hukum. Kesepuluh, keseimbangan, keserasian, dan keselarasan, yaitu keharusan setiap materi muatan peraturan perundang-undangan mencerminkan keseimbangan, keserasian, dan keselarasan, antara kepentingan individu, masyarakat dan kepentingan bangsa dan negara.

Kedua, pengkajian, analisis dan rekomendasi undang-undang terhadap nilai-nilai pancasila oleh BPIP. Kegiatan ini diatur dalam Keputusan Deputi Bidang Hukum, Advokasi dan Pengawasan Regulasi Badan Pembinaan Ideologi Pancasila Nomor 1 Tahun 2020 tentang Petunjuk Teknis Penyelarasan, Pengkajian Analisis dan Rekomendasi di Kedeputian Bidang Hukum, Advokasi dan Pengawasan Regulasi, tanggal 21 Februari 2020. Dalam Keputusan ini ditetapkan indikator nilai-nilai Pancasila dan variabel asas materi muatan sebagai tolok ukur dalam melakukan pengkajian, analisis dan rekomendasi. Indikator nilai-nilai Pancasila telah diuraikan sebelum sebelumnya dalam Tabel 3. Adapun berkaitan dengan variabel asas materi muatan yang digunakan oleh BPIP, terdapat dalam Lampiran I Keputusan, yang kesemuanya berjumlah 10, yang disebut asas materi muatan.

Kesepuluh asas materi muatan tersebut adalah, pertama, pengayoman, yaitu keharusan materi muatan peraturan perundangundangan berfungsi memberikan perlindungan dalam rangka menciptakan ketentraman masyarakat. Kedua, kemanusiaan, yaitu keharusan materi muatan peraturan perundang-undangan mencerminkan perlindungan dan penghormatan hak-hak asasi manusia serta harkat dan martabat setiap warga negara dan penduduk Indonesia secara proporsional. Ketiga, kebangsaan, yaitu keharusan materi 
muatan peraturan perundang-undangan mencerminkan sifat dan watak bangsa Indonesia yang pluralistik (kebhinekaan) dengan tetap menjaga prinsip negara kesatuan Republik Indonesia. Keempat, kekeluargaan, yaitu keharusan materi muatan peraturan perundangundangan mencerminkan musyawarah untuk mencapai mufakat dalam setiap pengambilan keputusan. Kelima, kenusantaraan, yaitu keharusan materi muatan peraturan perundang-undangan senantiasa memperhatikan kepentingan seluruh wilayah Indonesia dan materi muatan Peraturan Perundang-undangan yang dibuat di daerah merupakan bagian dari sistem hukum nasional yang berdasarkan Pancasila dan UUDNRI Tahun 1945.

Keenam, bhinneka tunggal ika, yaitu keharusan materi muatan peraturan perundang-undangan memperhatikan keragaman penduduk, agama, suku dan golongan, kondisi khusus daerah, dan budaya khususnya yang menyangkut masalah-masalah sensitif dalam kehidupan bermasyarakat, berbangsa, dan bernegara. Ketujuh, keadilan, yaitu keharusan materi muatan peraturan perundangundangan mencerminkan keadilan secara proporsional bagi setiap warga negara tanpa kecuali. Kedelapan, kesamaan kedudukan dalam hukum dan pemerintahan, yaitu keharusan materi muatan peraturan perundang-undangan tidak boleh memuat hal yang bersifat membedakan berdasarkan latar belakang, antara lain, agama, suku, ras, golongan, gender, atau status sosial. Kesembilan, ketertiban dan kepastian hukum, yaitu keharusan materi muatan peraruran perundang-undangan mewujudkan ketertiban dalam masyarakat melalui jaminan adanya kepastian hukum. Kesembilan, keseimbangan, keserasian, dan keselarasan, yaitu keharusan materi muatan peraturan perundang-undangan mencerminkan keseimbangan, keserasian, dan keselarasan, antara kepentingan individu dan masyarakat dengan kepentingan bangsa dan negara.

Kesepuluh asas materi muatan ini juga disebutkan bersifat kumulatif atau alternatif. Penggunaan asas ini disesuaikan dengan area substansi dari suatu perundang-undangan. Semakin peraturan perundang-undangan tersebut mengatur ke arah moralitas, maka 
asas yang digunakan semakin konfrehensif. ${ }^{26}$

Berdasarkan uraian di atas dapat dipahami bahwa ada peran pemerintah melalui BPHN dan BPIP untuk mengaktualisasi nilainilai Pancasila ke dalam undang-undang, yaitu dengan melakukan evaluasi dan pengakajian terhadap undang-undang yang telah diundangkan dan berlaku di masyarakat. Pada konteks ini, dasar hukum yang digunakan oleh BPHN dan BPIP dalam melakukan evaluasi dan kajian nilai-nilai Pancasila terhadap undang-undang ternyata ditemukan beberapa hal berikut. Pertama, objek evaluasi dan kajiannya adalah sama, yakni undang-undang yang sudah diundangkan dan berlaku dalam masyarakat. Kedua, tujuan evaluasi dan kajiannya juga sama, yakni rekomendasi untuk perubahan undang-undang atau mencabut undang-undang. Ketiga, indikator dan variabel yang digunakan adalah sama, yakni Pancasila dan asas materi muatan undang-undang.

Dengan demikian, penguatan dalam mengaktualkan nilainilai Pancasila yang dilakukan oleh BPHN dan BPIP tersebut di atas berlaku terhadap undang-undang setelah diundangkan. Model atau mekanisme evaluasi semacam ini sesungguhnya tidaklah efektif, karena tetap saja ditemukan adanya undang-undang yang tidak sesuai dengan nilai-nilai Pancasila. Untuk memperkuat aktualisasi nilai-nilai Pancasila dalam undang-undang, maka evaluasi ini seharusnya sudah dilakukan ketika undang-undang yang dibentuk sedang dipersiapkan. Ini berarti, Pancasila berperan sebagai penguji RUU sebelum disahkan undang.

Penguatan demikian itu perlu dilakukan pada substansi pasal dalam Undang-Undang tentang Pembentukan Undang-undang, yang mengatur pengujian RUU terhadap nilai-nilai Pancasila. Berkenaan dengan ini, BPHN juga mengakui dalam hasil evaluasi atas UndangUndang Nomor 12 Tahun 2011 dan Undang-Undang Nomor 15 Tahun 2019, “Tidak diaturnya secara tegas kewajiban melakukan

26 Keputusan Deputi Bidang Hukum, Advokasi dan Pengawasan Regulasi Badan Pembinaan Ideologi Pancasila Nomor 1 Tahun 2020 tentang Petunjuk Teknis Penyelarasan, Pengkajian Analisis dan Rekomendasi di Kedeputian Bidang Hukum, Lihat Lampiran I, hlm. 10. 
analisis ex-ante dan dilanjutkan dengan tahapan analisis dan evaluasi ex-post bagi produk peraturan perundang-undangan. Kedua analisis ini dapat mempengaruhi kualitas peraturan perundang-undangan yang dibuatnya". ${ }^{27}$

Hasil evaluasi BPHN tersebut menggunakan istilah pengujian RUU dengan analisis ex ante. Tentang istilah ini, ternyata ada juga dikenal dengan istilah lain yakni ex ante riview. Sebagaimana ditulis Victor Imanuel W. Nalle, ex ante riview merupakan pengujian undangundang sebelum disahkan. Mekanismeinimerupakan skema preventif untuk mencegah kerugian yang mungkin terjadi ketika undangundang tersebut telah diundangkan. ${ }^{28}$ Model pengujian semacam ini juga telah digunakan negara lain, misalnya Perancis. Sebagaimana dikatakan Jimly Ashidiqie, pengujian yang berlaku di Perancis adalah ex ante review, tetapi obyek pengujiannya bukanlah rancangan undang-undang yang belum disahkan oleh parlemen, melainkan rancangan yang sudah disahkan parlemen tetapi belum disahkan dan diundangkankan oleh Presiden. ${ }^{29}$ Di Hungaria, sebagaimana ditulis Andi Safriani, Mahkamah Konstitusi bahkan berwenang untuk melakukan pengujian secara ex ante atas rancangan undangundang, tata tertib parlemen sebelum diberlakukan, dan perjanjian internasional sebelum ditetapkan. ${ }^{30}$

Artikel ini berpendapat, model atau mekanisme pengujian terhadap rancangan undang-undang dapat pula diberlakukan di Indonesia sebagai upaya penguatan dalam mengaktualisasi nilainilai Pancasila ke dalam undang-undang pada tahapan pembentukan undang-undang. Hal ini didasari alasan bahwa ex ante dan ex ante review pada dasarnya sama-sama sebagai upaya pencegahan agar undang-undang yang dibentuk memiliki kualitas yang baik, termasuk

27 BPHN, "Laporan Akhir Kelompok Kerja Analisis”, hlm. 103.

28 Victor Imanuel W. Nalle, "Konstruksi Model Pengujian Ex Ante terhadap Rancangan Undang-Undang di Indonesia”, Jurnal Konstitusi, 10, 3 (2013), hlm. 440 .

29 Jimly Asshidiqie, Hukum Acara Pengujian Undang-Undang (Jakarta: Konpres, 2006), hlm. 5.

30 Andi Safriani, "Mahkamah Konstitusi di Beberapa Negara Perspektif Perbandingan Hukum”, Jurnal Al-Qadau, 6, 1 (2019), hlm. 88. 
di dalamnya sesuai dengan nilai-nilai Pancasila. Dalam hal ini pengujian rancangan undang-undang tersebut disarankan dilakukan pada tahapan pembahasan dalam kegiatan pembicaraan tingkat I sebelum disetujui bersama menjadi undang-undang oleh DPR pada pembicaraan tingkat II. Lembaga yang disarankan untuk melakukan pengujian ini adalah BPIP. Hal ini dimaksudkan untuk membedakan pengujian terhadap Undang-Undang terhadap UUDNRI 1945 oleh Mahkamah Konstutusi melalui kewenangan judicial review. Oleh karena itu kelembagaan BPIP harus diperkuat menjadi lembaga yang bukan bagian dari pemerintah, dan pembentukannya juga melalui undang-undang dan bukan melalui Peraturan Presiden.

\section{Kesimpulan}

Bagi suatu undang-undang yang dibentuk, Pancasila sesungguhnya memiliki kedudukan dan peran penting dan strategis. Ia merupakan sumber dari segala sumber hukum, dasar hukum nasional, dan juga cita hukum. Namun demikian, sejauh ini belum ada indikator dan variabel tentang nilai-nilai Pancasila yang menjadi pedoman dalam pembentukan suatu undang-undang, bahkan dalam Undang-undang tentang Pembentukan Peraturan Perundang-undangan. Kalaupun ada indikator dan variabel tentang nilai-nilai Pancasila, yang demikian itu merupakan pedoman yang berlaku dan digunakan oleh BPHN dan BPIP. Hanya saja, pedoman yang demikian itu hanya digunakan untuk mengevaluasi suatu undang-undang yang telah berlaku, bukan yang sedang dalam tahap pembentukan. Artikel ini mendorong agar nilai-nilai Pancasila dibuatkan indikator dan variabelnya, termasuk bisa jadi menggunakan pedoman yang sudah berlaku dan digunakan oleh BPHN dan BPIP, namun perlu diatur atau dituangkan dalam undang-undang, misalnya menjadi bagian dalam Undang-undang Pembentukan Peraturan Perundang-undangan. Model atau mekanisme penggunaannya juga perlu diubah, tidak sekadar untuk mengevaluasi, melainkan pula digunakan untuk menguji undangundang yang sedang dalam tahapan pembentukan atau sebelum diundangkan. Hal ini penting, agar nilai-nilai Pancasila menjadi 
semakin teraktualisasi dalam undang-undang yang dibentuk, dan di sisi lain, juga dapat dicegah materi muatan yang tidak sesuai dengan nilai-nilai Pancasila.

\section{Daftar Pustaka}

\section{Artikel, Buku, dan Laporan}

Asshidiqie, Jimly. Hukum Acara Pengujian Undang-Undang. Jakarta: Konpres, 2006.

Bo'a, Fais Yonas. "Pancasila sebagai Sumber Hukum dalam Sistem Hukum Nasional”. Jurnal Konstitusi, 15, 1(2018): 28-48. DOI: $10.31078 / \mathrm{jk} 1512$.

Hardiawanto, Heri, Fokky Fuad Wasitaatmadja, dan Jumanta Hamdayana. Spritualisme Pancasila. Jakarta: Prenada Media Group, 2018.

Huda, Ni'matul. "Kesesuaian Materi Muatan dalam Peraturan Perundang-Undangan dengan Nilai Pancasila”. Makalah dalam Seminar dan Presentasi Kajian, Analisis dan Rekomendasi Peraturan Perundang-Undangan Tahun 2020, diselenggarakan Badan Pembinaan Ideologi Pancasila, Yogyakarta, 12 November 2020.

Indrati S., Maria Farida. Ilmu Perundang-Undangan (Jenis, Fungsi dan Materi Muatan) Buku 1: Dikembangkan dari Perkuliahan Prof. Dr. A. Hamid S.Attamimi, S.H. Yogyakarta: Kanasius, 2007.

Krisnayuda, Backy. Pancasila \& Undang-Undang: Relasi dan Transformasi Keduanya dalam Sistem Ketatanegaraan Indonesia. Jakarta: Kencana, 2016.

Latif, Abdul. Hukum dan Peraturan Kebijaksanaan (Beleidsregel) pada Pemerintahan Daerah. Yogyakarta: UII Press, 2020.

Latif, Yudi. "Menjaga Negara-Bangsa, Menjaga Moral Republik: Menimbang Ulang Negara-Bangsa”. Makalah dalam Orasi Widjojo Nitisastro Memorial Lecture, diselenggarakan Akademi Ilmu Pengetahuan Indonesia. https://www.aipi.or.id/assets/ images/widjojo/file_1546620258.pdf. Diakses 6/11/2020. Nalle, Victor Imanuel W. "Konstruksi Model Pengujian Ex Ante 
terhadap Rancangan Undang-Undang di Indonesia”. Jurnal Konstitusi, 10, 3 (2013): 439-459.

Prasetyo, Teguh dan Arie Purnomosidi. Membangun Hukum Berdasarkan Pancasila. Bandung: Nusa Media, 2014.

Purwanti, Ani. "Advokasi dan Pengawasan Regulasi Badan Pembinaan Ideologi Pancasila, Rekomendasi Kebijakan dan Regulasi Berlandaskan Pancasila”. Paparan pada Seminar dan Presentasi Kajian, Analisis dan Rekomendasi Perundang-undangan Tahun 2020, diselenggarakan Badan Pembinaan Ideologi Pancasila, Yogyakarta, 11 November 2020.

Republik Indonesia, Badan Pembinaan Hukum Nasional Kementerian Hukum dan Hak Asasi Manusia. "Laporan Akhir Kelompok Kerja Analisis dan Evaluasi Hukum terkait Penguatan Ideologi Pancasila Tahun 2019”. https://www.bphn.go.id/data/ documents/laporan_akhir_pip.pdf.

Republik Indonesia, Badan Pembinaan Hukum Nasional Kementerian

Hukum dan Hak Asasi Manusia. "Pedoman Analisis dan Evaluasi Hukum Nomor PHN-01.HN.01.03 Tahun 2019”. https:// www.bphn.go.id/data/documents/pedoman_aeh_no_phn-01. hn.01.03_tahun_2019.pdf.

Republik Indonesia, Badan Pengembangan dan Pembinaan Bahasa

Kemenetrian Pendidikan dan Kebudayaan. Kamus Besar Bahasa Indonesia. https:/ / kbbi.web.id. Diakses 6/11/2020.

Republik Indonesia, Mahkamah Konstitusi. "Rekapitulasi Perkara Pengujian Undang-undang”. https:// mkri.id/index.php?page=web.RekapPUU. Diakses 6/2/2020.

Rhiti, Hyronimus. Cita Hukum dan Postmodern: Kajian Gagasan Ekologis Pancasila. Yogyakarta: Genta Publishing, 2020.

Safriani, Andi. "Mahkamah Konstitusi di Beberapa Negara Perspektif Perbandingan Hukum”. Jurnal Al-Qadau, 6, 1 (2019): 83-90. DOI: 10.24252 / al-qadau.v6i1.9460.

Sidharta, B. Arief. Ilmu Hukum Indonesia: Upaya Pengembangan Ilmu Hukum Sistematik yang Responsif terhadap Perubahan Masyarakat. Bandung: Unpar Press, cetakan kedua, 2017.

Sutiyono. "Reaktualisasi Pancasila dalam Membentuk Good Citi- 
zenship di Era Global”. Dalam Revitalisasi Ideologi Pancasila dalam Aras Global Perspektif Negara Hukum: Prosiding Seminar Nasional Dies Natalis Fakultas Hukum Unnes ke-9 Tahun 2016, 603615. Semarang: Badan Penerbit Fakultas Hukum Universitas Negeri Semarang, 2017.

Thontowi, Jawahir. Pancasila dalam Perspektif Hukum: Pandangan terhadap Ancaman the Lost Generation. Yogyakarta: UII Press, 2016.

Wahyudi, Agus. "Ideologi Pancasila: Doktrin yang Komprehensif atau Konsepsi Politis?”. Jurnal Filsafat, 39, 1 (2006): 94-115.

Widisuseno, Iriyanto. "Azas Filosofis Pancasila sebagai Ideologi dan Dasar Negara”. Humanika, 20, 2 (2014): 62-66.

\section{Peraturan dan Putusan Hukum}

Republik Indonesia. Undang-Undang Dasar Negara Republik Indonesia Tahun 1945.

Republik Indonesia. Undang-Undang Nomor 12 Tahun 2011 tentang Pembentukan Peraturan Perundang-Undangan. Lembaran

Negara Tahun 2011 Nomor 82, Tambahan Lembaran Negara Nomor 5234.

Republik Indonesia. Undang-Undang Nomor 15 Tahun 2019 tentang

Perubahan atas Undang-Undang Nomor 12 Tahun 2011 tentang Pembentukan Peraturan Perundang-Undangan. Lembaran Negara Tahun 2019 Nomor 183, Tambahan Lembaran Negara Nomor 6398.

Republik Indonesia. Peraturan Presiden Nomor 87 Tahun 2014 tentang Peraturan Pelaksana Undang-Undang Nomor 12 Tahun 2011 tentang Pembentukan Perundang-Undangan. Lembaran Negara Tahun 2014 Nomor 199.

Republik Indonesia, Dewan Perwakilan Rakyat. Peraturan Dewan Nomor 1 Tahun 2014 tentang Tata Tertib.

Republik Indonesia, Kementerian Hukum dan Hak Asasi Manusia.

Peraturan Menteri Nomor 20 Tahun 2015 tentang Tata Cara dan Prosedur Pengharmonisan, pembulatan dan Pemantapan Konsepsi Rancangan Peraturan Perundang-Undangan. 
RepublikIndonesia, Deputi BidangHukum, Advokasidan Pengawasan Regulasi Badan Pembinaan Ideologi Pancasila. Keputusan Nomor 1 Tahun 2020 tentang Petunjuk Teknis Penyelarasan, Pengkajian Analisis dan Rekomendasi di Kedeputian Bidang Hukum. 